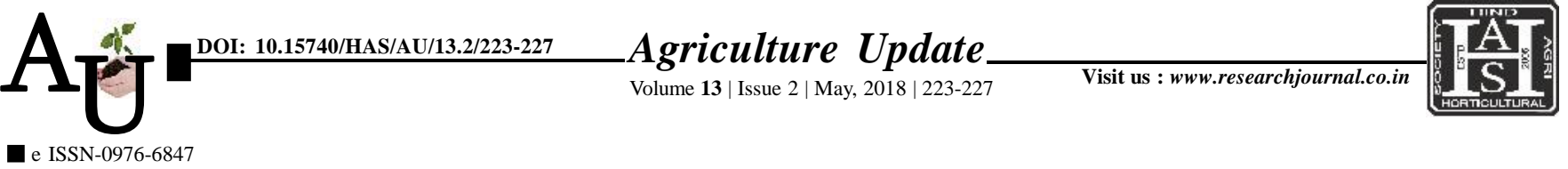

\title{
Research Aтticle: Impact of e-mandi on commodity prices using double difference method
}

\section{C.S. Sathish Gowda, Aditya and Amit Kar}

Article Chronicle: Received :

19.03.2018;

Revised :

10.04.2018;

Accepted :

22.04.2018

KEY WoRds:

E-mandi, APMC,

Difference in

difference method
SUMMARY : Study on impact of electronic initiatives vis-à-vis e-mandi on agricultural marketing was carried out in selected APMC markets of Karnataka during the year 2017. E mandi provides complete end to end solution by computerizing of all the activities from gate entry to exit. One of the important provisions under this system are electronic tendering instead of manual tendering, integration of APMC markets and online payment etc. Electronic tendering process reduces the malpractices like price manipulations etc. and brings higher competition and efficiency in marketing process. Price realization in e-mandi is more compare to prices in non e-mandi. In copra and onion Rs. 292 and 113 higher prices compare to prices in non e-mandi, respectively. Majority of the stakeholders involved in e-mandi are satisfied with the different provisions of e-mandi. But, some of the components like participation of traders from different APMC market, lack of proper grading system and online payment system is not upto satisfactory level, which hinders the farmers to realize better prices for their produce.

How to cite this article : Gowda, C.S. Sathish, Aditya and Kar, Amit (2018). Impact of e-mandi on commodity prices using double difference method. Agric. Update, 13(2): 223-227; DOI : 10.15740/HAS/AU/13.2/223-227. Copyright@2018: Hind Agri-Horticultural Society.
Author for correspondence : C.S. Sathish Gowda Division of Agricultural Economics, IARI, New Delhi (India)

Email:cssg86@gmail.com

See end of the article for authors' affiliations 